\title{
ドライイメージングフィルムへのゴム材料の適用
}

\author{
塚 田芳 久*1. 都 築 博 彦*2. 吉 岡 康 弘*3
}

\section{Rubber Materials for Dry Imaging Films}

Yoshihisa TSUKADA, Hirohiko TSUZUKI, Yasuhiro YOSHIOKA (Fuji Photo Film, 210, Nakanuma, MinamiashigaraShi, Kanagawa, 250-0193, Japan)

Dry imaging film DI-HL (hereafter Film A) has been developed for a new medical imaging system that is distinguished from conventional film systems by digitization and no waste water. This film is produced with a water-based emulsion coating technology that is much eco-friendly. SBR latex is used for a binder of light-sensitive layer in Film A where images are formed of silver. This SBR latex was especially designed for Film A to give excellent image archivability in comparison with our old type SBR latex. Besides SBR latex, layer structures and image formation mechanism of Film A, and a water-based emulsion coating technology are described.

Key Words : SBR Latex, Dry Imaging Film, Image Archivability, Image Formation Mechanism, Water-based Emulsion Coating Technology

\section{1.は じめ に}

医療用画像の分野において, 従来の感光材料であるX 線フィルムからは，アナログ画像情報が得られるのみであ ったが，富士コンピューテッドラジオグラフィー技術 (FCR)などにより，X線画像情報のデジタル化は進行した. さらにX線投影像のみならず，コンピューター断層撮影 (CT) や磁気共鳴画像 (MRI) などにより, 得られた断層像 のデジタルデータの画像出力する機会 も，ますます増加してきている．この ように医療の現場では, デジタル情報 の出力メディアとしてドライイメージ ングフィルムの重要性が高まってお り, 検査・診断になくてはならない存 在となっている(図 1).

このようなデジタル化という観点た けではなく, 感光材料を取り巻く状況 は, 環境という視点でも変化してきて いる. 従来の湿式型の感光材料は, 現 像・定着・水洗という液による処理が 必要なため, 大量の廃液やその臭気と いった問題を抱えていた. 1993 年の 「廃棄物その他の投棄による海洋污染
の防止に関する条約」付属書改訂を契機に, 我が国では 1996年 1 月 1 日から湿式写真材料の処理廃液の海洋投棄 が全面的に禁止されることになり, 写真处理液の使用量低 隇 ${ }^{1)}$, 処理廃液の無害化技術の研究 ${ }^{2,3)}$ が数多く進められ た.

このようなすう勢のなかで脚光を浴びることになったド ライイメージングフィルムは, Minnesota Mining and Manufacturing社で発明されたものであり ${ }^{4,5)}$, 有機銀塩

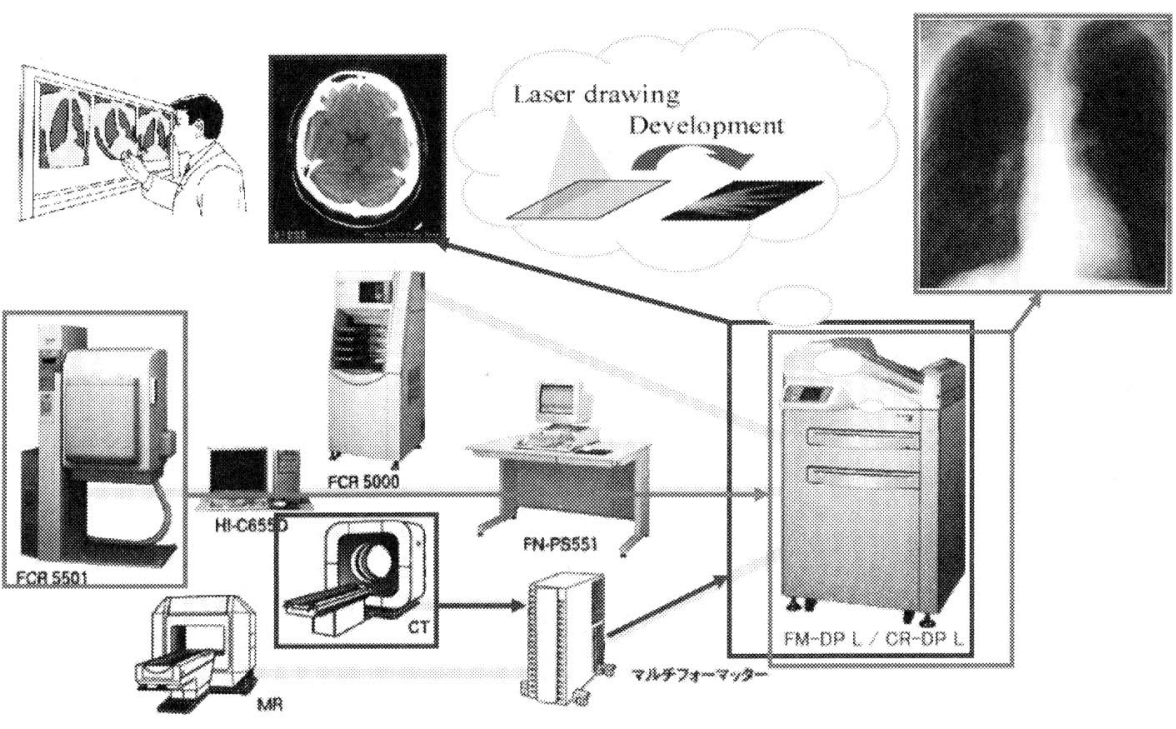

四 1 デジタル化された医療用画像 
を利用した処理液が不要な感光材料である１994年には 海外で乾式熱現像方式の医療用レーザーイメージャー感材 が発売され, 従来型湿式写真からの廃液による環境負荷の 低滅にとどまらず，地震などの災害時の水が不足する状況 下でも，現像機を稼動させられることから大きく注目され た.

この有機銀塩を利用したドライイメージングフィルム は，大量の有機溶媒塗布により製造されるため，有機溶媒 の回収・再利用に伴うプロセスには多くのエネルギーと経 費が必要であった。有機溶媒塗布のドライイメージングフ イルムでは, 脱写真処理廃液化により画像出力以降での環 境負荷を低隇しても, 従来の湿式写真方式に対して製造時 には，環境負荷を増大させる側面を有していた，脱写真処 理廃液のみならず，製造時の環境負荷も従来の湿式写真方 式と同様にする必要が認識され，水溶媒で塗布・製造でき るドライイメージングフィルムが開発された。

本稿では, 水系で製造されるドライイメージングフィル ムの概要, およびその画像形成原理, ドライイメージング フィルムの感光層用に新たに開発したゴム材料のひとつで あるスチレンーブタジェンゴムラテックス（以下，SBR テックス)の適用、そして水溶媒塗布について紹介する.

\section{2. ドライイメージングフィルム}

\section{1 ドライイメージングフィルムの層構成と使用材料}

幣社ドライイメージングフィルムである富士ドライ画像 記録用フィルム DI-HL (以後，フィルム A と略す)の層構 成の模式図 (図 2 ) とフィルム断面の電子顕微鏡写真 (図 3 ) を示す．感光層側は保護層, 中間層, 感光層の 3 層から構 成され，裏面側はアンチハレーション $(\mathrm{AH})$ 層と保護層の 2 層から構成される. 感光層には光センサーとなる超微粒 子ハロゲン銀乳剂のほか, 非感光性脂肪酸銀塩(銀供給体), 熱現像剤(還元剤)，銀イオン輸送剤，カブリ防止剤，画像 安定剂などが含まれ，SBRラテックスからなるバインダ 一により，画像形成の中枢を担う層を形成している。感光 層側の保護層には，マット剤のほか，熱現像反応を 補助する化合物が含まれており，画像形成面の耐傷 性や耐接着性などの物理性を向上させるとともに現 像反応にも寄与している. 毫面側の $\mathrm{AH}$ 層にはアン チハレーション色素が含まれ，画像の鮮鋭度を向上 させている．董面側の保護層は感光層側と同様に物 理性に寄与している。

\section{2 画像形成原理}

フィルムAの画像形成原理を図 4 で説明する. レーザー光で露光されたハロゲン化銀粒子が現像の 活性中心となる潜像 $\left(\mathrm{Ag}^{0}\right)$ を形成する．続く約 120 ${ }^{\circ} \mathrm{C}$ の熱現像過程で，共存する非感光性脂肪酸銀塩は 相転移温度以上に熱されるため, 分子運動が活発に
なる．この脂肪酸銀塩から銀イオン輸送剂を経由して銀イ オンがハロゲン化銀粒子近傍に輸送され，潜像に銀イオン が供給される。ここで潜像が触媒として働き, 熱現像剤が 作用して銀イオンは金属銀に還元される ${ }^{6)}$.この現像銀に 対し，銀イオン輸送剂が銀イオンを輸送し，金属銀のフィ ラメントが成長し，現像銀が形成される。

未露光のハロゲン化銀では速やかな熱現像反応は起こら ず，一部のハロゲン化銀にカブリ銀の形成がゆっくり進行 する。ここでカブリ防止剂がカブリ銀の形成を抑制し，力 ブリの低い高画質の画像が形成される．熱現像は 14 秒で 終了し，フィルムが室温まで泠却されると，有機銀塩は結 晶状態に再び戻り，分子運動は抑制される．同時に現像反 応に関与した化合物の活性も低下し，安定した画像が形成 される。

また，熱現像過程の後には特別な定着過程が設けられて 抢らず，反応性素材がそのままフィルム中に残存しており， フィルムに強い光が露光された場合や熱がかかるような保 管条件では，カブリの上昇や変色などの画質の劣化を招く 可能性を高めてしまう。しかし，記録材料から除去される 物質がなく, 廃液, 廃材を出さないメリットであり, この メリットを保ちながら，現像活性の向上と画像保存性の両 立を満たすことが，ドライイメージングフィルムの最大の 課題ともいえる.

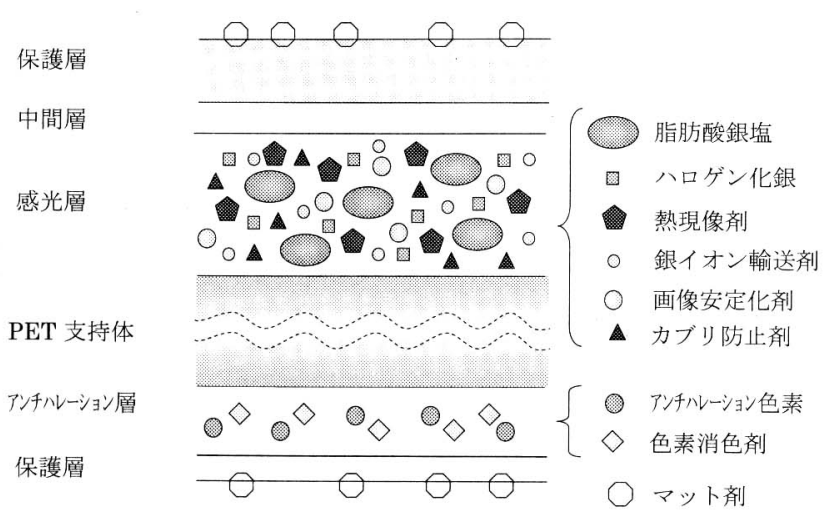

図 2 フィルム $\mathrm{A} の$ 層構成

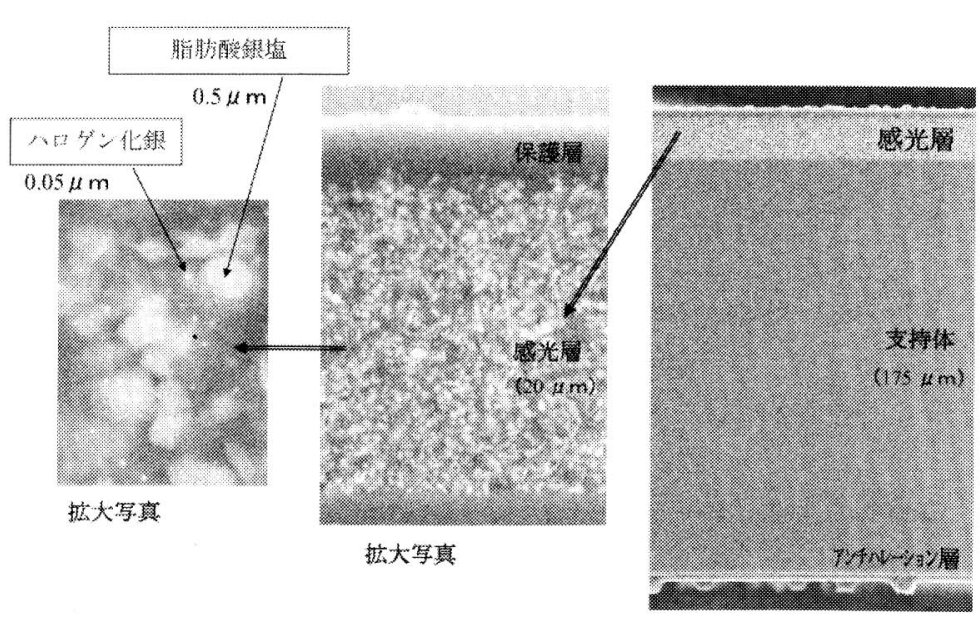

図 3 走査型電子顕微鏡によるフィルム $\mathrm{A}$ の断面写真 


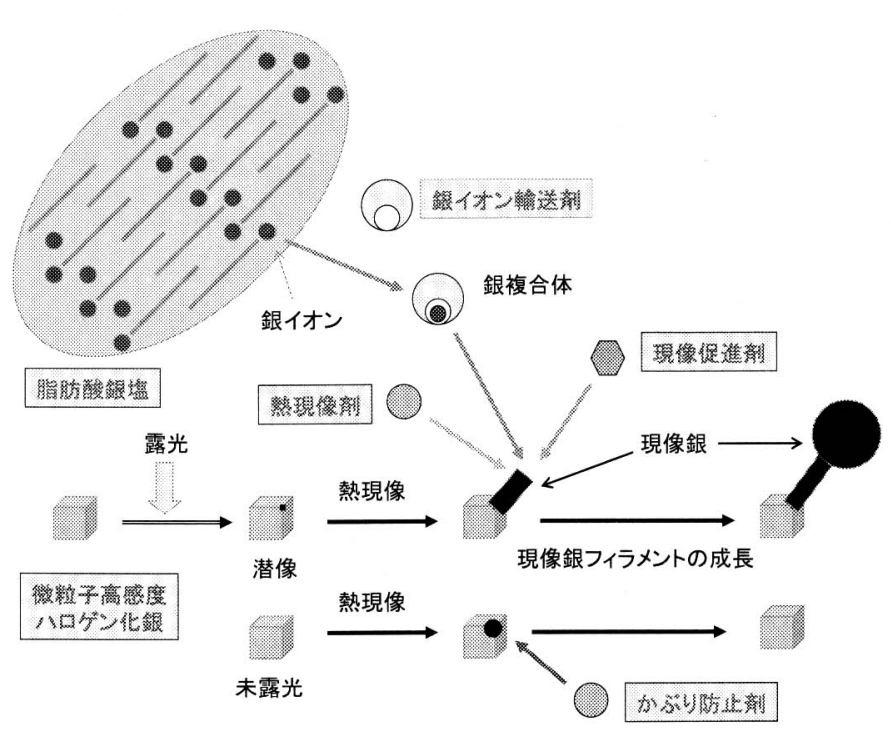

図 4 フィルムAの画像形成原理

\section{3. ドライイメージングフィルムにおけるゴム材料}

\section{1 ドライイメージングフィルム感光層バインダーの 選択}

有機溶媒塗布で製造されるドライイメージングフィルム には，感光層のバインダーとしてポリビニルブチラールを 使用している。これは画像形成に必要な疎水性化合物を溶 解・保持でき，またカブリの原因となる水分を排除できる という観点で行ったポリマーの選択と考えることができ る. また, 通常の有機溶媒への溶解性も十分であり, 有機 溶媒塗布により十分な成膜性を確保できていることも選択 の重要な要件となっている.

ドライイメージングフィルムは熱による現像を利用した システムのため, ポリマーの熱物性は重要であり、なかで もガラス転移温度 $\left(T_{g}\right)$ はポイントとなる物性である。ポリ ビニルブチラールの $T_{g}$ は室温以上の約 $70{ }^{\circ} \mathrm{C}$ 有してお り，100 ํ以上で熱現像されるときには, 感光層のバイン ダーとしてのポリマーの運動性が向上し, 熱現像反応が促 進されやすくなる，逆に室温付近の保存時ではポリマーの 運動性が低下し、不必要な反応が進行しにくくなる。この ようにポリマーの $T_{g} に は 、$ 熱現像時と保存時の熱的な環 境の差別性を助長しているという側面がある.

前述のような有機溶媒に関連する製造時の問題を解決す るには，このポリマーと同様の疎水性皮膜を水溶媒塗布で 実現する必要があった，塗布までは水溶媒で扱え，塗布乾 燥後には十分に疎水性となるバインダーの開発を開始し, 水性ペイントなどで活用されている水性ラテックスに着目 した．このラテックスの必須特性としては, 感光層を保持 するため製品状態で膜を形成することと, 最低造膜温度 (MFT) が現像温度より十分低いことが挙げられる. 現像 温度では各種素材が溶融して現像を開始する状態となるた め, 製造工程の温度は現像温度より十分低い必要がある。

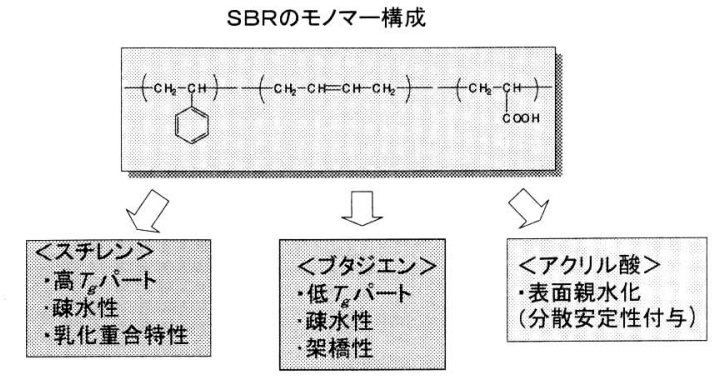

図 5 SBRモノマーの機能

更に，有機溶媒塗布で製造されるドライイメージングフィ ルムとは異なり，水溶媒塗布で乳化物であるラテックスを 含む塗布液を用いるため, 塗布したフィルムの面状に影響 の出る凝集物やラテックス粒子の粗大粒子が非常に少ない ことも必要である．このような物性や特徴をもち，ドライ イメージングフィルムに適した疎水的な膜を形成するバイ ンダーとして, 種々の水性ラテックスを検討した結果, SBRラテックスを見出した.

\section{2 新開発 SBRラテックス}

1）モノマーの機能

ドライイメージングフイルムに用いるSBRラテックス は図 5 のようなモノマーにより構成され，室温付近に $T_{g}$ を有したものである，スチレンはポリマーの高 $T_{g}$ パート に相当し，乳化重合適性のある疎水性モノマーである．ブ 夕ジエンはポリマーの低 $T_{g}$ パートであり，疎水性かつ架 橋性のモノマーである。このスチレンとブタジエンの組成 比により，ポリマーの $T_{g}$ を適宜に設定でき，さらに架橋 度も調整できることから，フィルムの膜質のコントロール が可能である．また，アクリル酸はごく少量を共重合する ことでラテックス表面を親水性化し，ラテックスの分散安 定性を付与している。このアクリル酸由来のカルボキシル 基の効果は，SBRラテックスの合成時だけではなく，感 光層塗布液の調製時や滁工時の $\mathrm{pH}$ 変化への緩衝能も与元 ている.このようにモノマー構造由来の機能は、感光層と してのバインダーだけではなく、ラテックス本体としての 製造適性、感光層塗布液調整時の安定性付与、フィルム塗 工時の面状等の機能へ影響を及ぼしてる.

2 ) SBRラテックスの重合処方設計と性能

従来 SBR ラテックスは乳化重合により合成され, 重合 のためにモノマー以外には乳化剂, 連鎖移動剂, 重合開始 郕などを添加している。これまで紙塗工用など様々な用途 に適したSBRラテックスが種々上市されている。これら のラテックスには分散安定性や防腐性などのために種々の 添加剂が含有され, 個々の用途に適切なラテックス液物性 や，ラテックスから形成されるポリマーフィルムの膜物性 を確保しているのが，一般的である. ドライイメージング フィルムには画像形成のための銀を含んでおり，銀が上記 のようなラテックスの添加剤と反応する場合がある．ドラ 
SBRラテックス添加剂を必要最小限にする重合処方

銀への影響を徹底的に排除

<一般的なSBR添加剧>

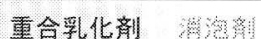

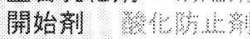

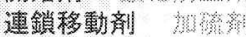

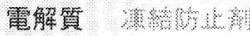

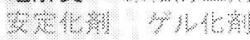

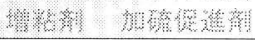

ドライイメージングフィルム専用SBRラテックス

図 6 ドライイメージングフィルム用SBRラテックス開発指針

イイメージングフィルムのカブリの上昇する原因の一つ は,この銀とラテックスの添加物との副反応であった？そ こで，ラテックスの製造適性を両立しながら徹底的に銀へ の影響を排除したドライイメージングフィルム専用 SBR ラテックスを設計した(図 6 )。種々の添加剤を可能な限り 除去し, 乳化重合が可能で, かつ目標とする感材性能・膜 物性を確保できる必要十分な重合乳化剂, 重合開始剂, 連 鎖移動剂，電解質で構成した重合処方を構築し，ドライイ メージングフィルムに最適な SBR ラテックスの合成を可 能とした。その結果，以前から使用していたSBRラテッ クスに比較して，ドライイメージングフィルムの重要な課 題である画像保存性を図 7 のように改良できることがわか った.

今回の新開発したSBRラテックスの重合処方の主な要 因が，フィルム Aに採用した処方值から変動した場合の ラテックス物性およびドライイメージングフィルム性能変 化についての関係を表 1 にまとめた．最高の性能と製造適 性を兼ね備えるため、様々な処方因子をドライイメージン グフィルム専用へ徹底的に最適化する過程で得られた知見 である。

\section{4. 水 溶 媒 塗 布}

フィルム $\mathrm{A}$ は, 図 8 のように多層を水系の同時重層塗 布して製造される。まず，塗布液は塗布ダイ上部のスライ ド面を積層して流される，次いで，塗布液はバックアップ ロール上を高速で通過する支持体に移し変えられる。この

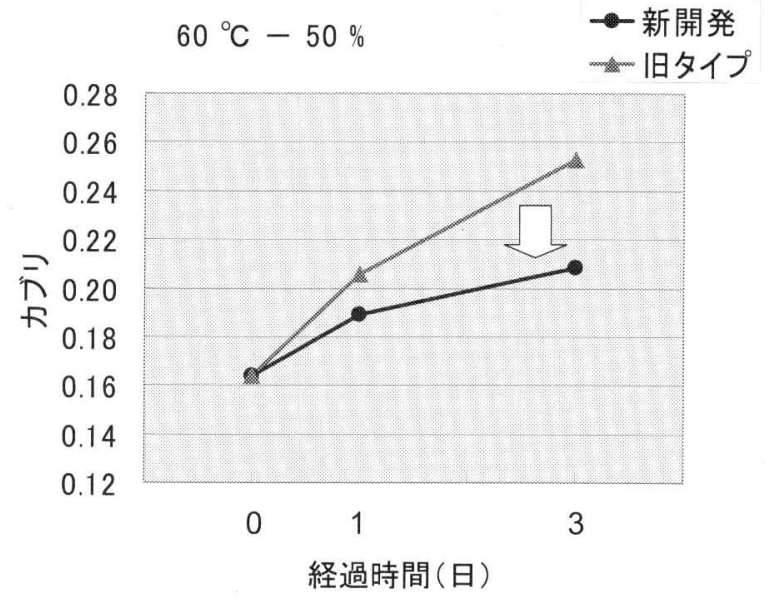

図 7 高温・暗保存時の新開発SBR ラテックスの 画像保存性改良効果

とき, 塗布液は狭い塗布ビード(液溜部) 内で高速に搬送さ れる支持体で引き伸ばされ，強いせん断を受ける，さらに， 支持体に載った塗布液は風で乾燥されドライイメージング フィルムとなる。この乾燥の時には塗布液の引き伸ばしは なくせん断は弱い.

この塗布ダイから支持体に移る塗布ビードと乾燥では， 好適な物性が異なる，具体的には，せん断が強い塗布ビー ドではビード自体を安定化するため粘度が低いことが好ま しく，乾燥においては高風量に耐えるため粘度が高い必要 がある。

水性ラテックスバインダーを用いた際にも，ゼラチン同 様に高風量の乾燥に耐える機構が必要となる．有機銀塩と 水性ラテックスを混合する実験により，弱いせん断では粘 度が高く，強いせん断では粘度が低くなるチキソトロピー 性を発現することを見出した。このチキソトロピー性は， 水性ラテックスと有機銀塩は弱い荷電相互作用により軟凝 集体を形成し，強いせん断で容易に解けるためと考えてい る(図 9 ).

このように塗布液にチキソトロピー性を発現させたこと で，原理的には高速塗布可能な液を見出した。しかしなが ら，チキソトロピー流体を先に述べたような高速同時重層 した例は世の中になかった，チキソトロピー性の制御，つ

表 1 SBR ラテックスの重合処方因子とラテックス物性・感材性能への影響

\begin{tabular}{|c|c|c|c|}
\hline 乳化重合処方因子 & 配合 & ラテックス物性 & 感材性能 \\
\hline \multirow{2}{*}{ スチレン ブタジエン組成比 } & 大 & 高 $T_{g} \quad$ 化 & 画像保存性良化 成膜性悪化 \\
\hline & 小 & 低 $T_{g}$ 化 & 画像保存性悪化 成膜性良化 \\
\hline \multirow{2}{*}{ 重合乳化刘 } & 多 & 小粒径化 高粘度化 & 画像保存性悪化 \\
\hline & 少 & 大粒径化＼cjkstart低粘度化 & 画像保存性良化 \\
\hline \multirow{2}{*}{ 重合開始剤 } & 多 & 小粒径化 ゲル分増加 & 画像保存性良化 \\
\hline & 少 & 大粒径化 残存モノマー増加 & 画像保存性悪化 \\
\hline \multirow{2}{*}{ 連鎖移動剂 } & 多 & ゲル分減少 & 加工脆性悪化 画像保存性悪化 \\
\hline & 少 & ゲル分増加 & 成膜性悪化 \\
\hline ハロゲンイオン & 多 & 低粘度化 & 画像保存性悪化 \\
\hline アンモニア(中和塩基) & 多 & $\mathrm{pH}$ 上昇． & 画像色調 青味増加 \\
\hline
\end{tabular}




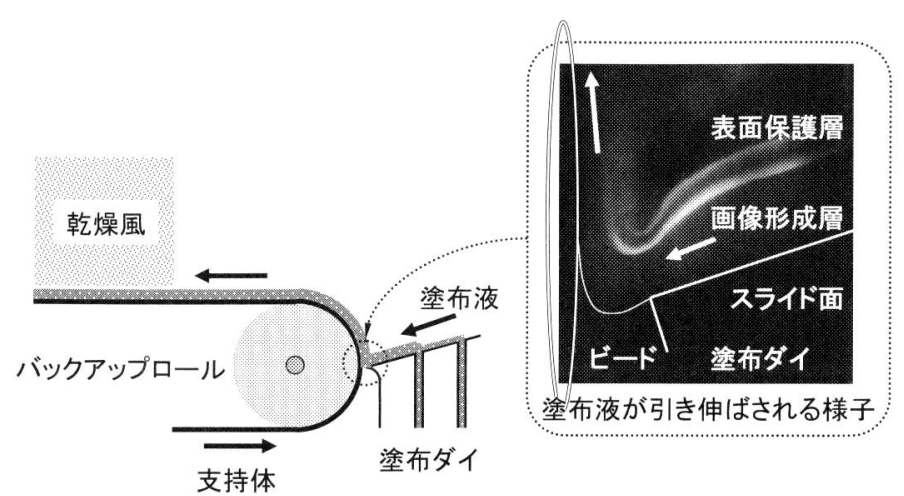

図 8 感光材料の塗布

まり弱いせん断から強いせん断の広範囲に渡って粘度を変 更できる技術の確立，さらに塗布液の流れの観察とシミュ レーションによる最適な塗布ダイ設計により，ドライイメ ージングフィルム塗布技術として我々独自のものを開発で きた。

\section{5.おわりに}

これまで写真感光材料の分野に扔いて, SBRラテック スのようなゴム材料は，重要だが補助的な役割である支持 体への下塗りに主に使用されてきた．上述してきたドライ イメージングフィルム用 SBRラテックスのように，感光 層という感光材料の中心的な機能を発現する層に，ゴム材 料が用いられることはなかった. ドライイメージングフィ ルム用に極限までSBRラテックスの可能性を引き出すこ とにより，フィルムAに新開発 SBRラテックスを導入で きた. SBRラテックス以外にも超微粒子高感度ハロゲン 化銀乳剤技術 - 迅速熱現像技術 - 色調調整技術 - 画像安定 化技術を新たに開発導入し，ドライイメージングフイルム の高速・大量処理と高画質化の達成を可能とした。さらに 水塗布ドライイメージングフィルムとして，フィルムの使 用環境や製造環境の改善以外にも，有機溶媒の削減のみな らず $20 \%$ の銀量低滅化を達成し，省資源の観点でも環境 への寄与に貢献できた。

弊社のこれまでの水系塗布ドライイメージングフィルム の技術に対し，第33回日化協技術賞，第 1 回GSC 賞(グリ ーン・サスティナブル・ケミストリー)，第52回日本化学 会化学技術賞を受賞した ${ }^{7)}$ ．今後もさらに，環境に配慮し た感材技術開発のなかで，ゴム材料の可能性をさらに追求 していきたい.

\section{References}

1 ) Suzuki, T., Murase, S., Nanami, M., Saotome, S., Arai, N., Itoh, T.: Fuji Medical Review, 3, 32 (1994)

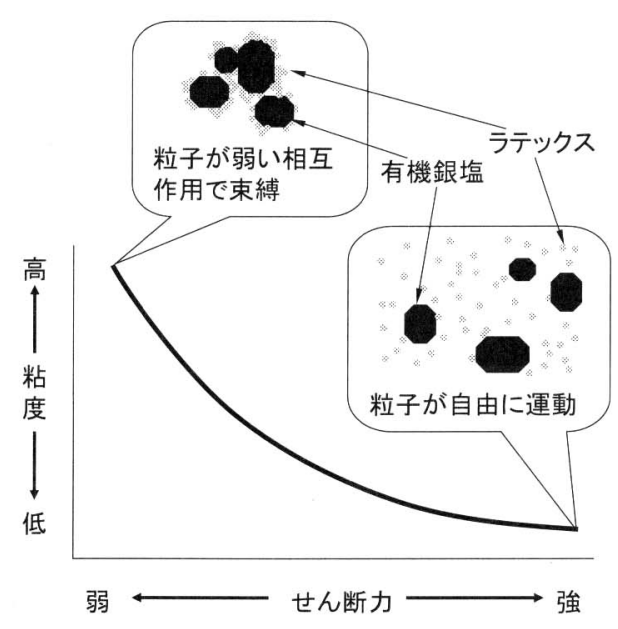

図 9 有機銀塩とラテックスのせん断による粘度変化

2 ) Miyazaki, H.: Nippon Shashin Gakkaishi, 63, 28 (2000)

3 ) Tsuzuki, H., Miyazaki, H.: Nippon Shashin Gakkaishi, 57, 240 (1994)

4 ) Owen, R.: US Patent 2910377 (1959)

5 ) Morgan, D. A.: Jpn. Tokkyo Koho 1968-4924 (1968)

6 ) Maekawa, T., Yoshikane, M., Fujimura, H., Toya, I.: J. Imaging Sci. Technol., 45, 365 (2001)

7) Tsuzuki, H.: Chem. Rec., 3, 322, (2004)

\section{日本語表記参考文献}

1）鈴木俊昭，村瀬正一，名波昌治，早乙女滋，新井直樹，伊藤 忠： 富士メディカルレビュー，3，32（1994）

2 ）宮崎英男：日本写真学会誌，63，28（2000）

3 ）都築博彦, 宮崎英男：日本写真学会誌，57，240（1994）

5 ） Morgan, D. A. : 特公昭 43-4924

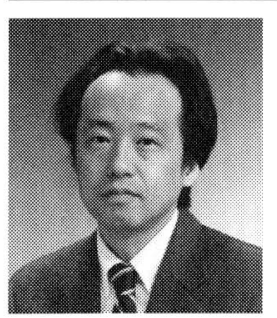

*1富士写真フイルム株 $R \& D$ 統括本部有機合成 化学研究所 ( ₹ 250-0193 神奈川県南足柄市 中沼 210$)$, 主任研究員. 昭和 63 年 東京工 業大学総合理工学研究科生命化学修士課程 修了。同年，富士写真フイルム侏入社，現 在に至る．専門は，高分子化学

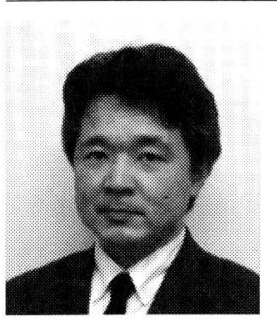

*2富士写真フイルム侏 $R \& D$ 統括本部先端コア 技術研究所 ( $\bar{\top} 258-8577$ 神奈川県足柄上郡 開成町牛島 577), 主任研究員. 昭和 63 年, 東京大学大学院工学系研究科修士課程修了. 昭和 63 年，富士写真フイルム(侏入社，現在 に至る，専門は，電気化学，分析化学

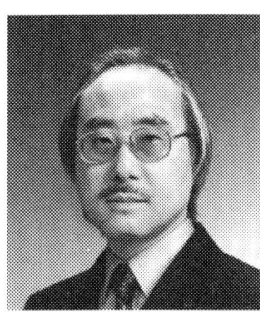

*3富士写真フイルム侏メデイカル開発センタ - ( ₹ 250-0193 神奈川県南足柄市中沼 210) 部長. 昭和 55 年, 東京大学大学院理学系研 究科化学専攻修士課程修了。同年富士写真 フイルム秼入社，現在に至る，専門は，写 真感光材料, 有機化学 